\title{
Control of Root and Stem Rot of Cucumber, Caused by Fusarium oxysporum f. sp. radicis-cucumerinum, by Grafting onto Resistant Rootstocks
}

\author{
G. C. Pavlou, National Agricultural Research Foundation (N.AG.RE.F.), Agricultural Research Station, 72200 \\ Ierapetra, Crete, Greece; and D. J. Vakalounakis and E. K. Ligoxigakis, National Agricultural Research Founda- \\ tion (N.AG.RE.F.), Plant Protection Institute, P.O. Box 2228, 71003 Heraklio, Crete, Greece
}

\begin{abstract}
Pavlou, G. C., Vakalounakis, D. J., and Ligoxigakis, E. K. 2002. Control of root and stem rot of cucumber, caused by Fusarium oxysporum f. sp. radicis-cucumerinum, by grafting onto resistant rootstocks. Plant Dis. 86:379-382.

Root and stem rot of cucumber (Cucumis sativus), caused by Fusarium oxysporum f. sp. radicis-cucumerinum, is a new catastrophic disease of greenhouse crops in Greece and some other countries. No effective disease control methods are available, apart from soil disinfestation by fumigation with methyl bromide and disinfection of internal space of greenhouses with a formaldehyde solution. However, it is anticipated that the use of methyl bromide will be phased out in Greece by 1 January 2005. Therefore, alternative measures for disease management are urgently required. In this study, the efficacy of grafting commercial Dutch type cucumber hybrids onto various cucurbits, used as rootstocks, was examined in growth chamber and greenhouse experiments. Of the nine commercial Cucurbita spp. evaluated, six, A27, Cucurbita Ficifolia, Patron $\mathrm{F}_{1}$, Peto $42.91 \mathrm{~F}_{1}$, TS-1358 $\mathrm{F}_{1}$, and TZ-148 $\mathrm{F}_{1}$, found resistant to $F$. oxysporum $\mathrm{f}$. sp. radicis-cucumerinum, were selected to serve in subsequent greenhouse experiments as rootstocks for grafting the susceptible cv. Brunex $F_{1}$. Of these, Peto $42.91 \mathrm{~F}_{1}$, TS-1358 $\mathrm{F}_{1}$, and TZ$148 \mathrm{~F}_{1}$ were found to be superior to the others due to their horticultural performance under the climatic conditions prevailing in Crete during the cucumber crop season, late October to late May. This study shows that grafting commercial Dutch type cucumber hybrids onto various resistant Cucurbita rootstocks could be used as an alternative control method to methyl bromide for root and stem rot.
\end{abstract}

Cucumber (Cucumis sativus L.) is an important vegetable crop in Greece and many other countries (14). Root and stem rot, caused by Fusarium oxysporum Schlechtend.:Fr. f. sp. radicis-cucumerinum D.J. Vakalounakis, is a new disease of cucumber which was recorded for the first time in Crete, Greece, in 1989. At present, it is the most destructive disease of greenhouse-grown cucumber in Crete and Peloponnese, Greece $(15,16)$. This disease also appeared in Canada in 1994, in France in 1998, and in Spain in 1999, causing significant losses in greenhouse-grown cucumbers $(9,11,12)$. Affected plants wilt at the fruit-bearing stage, especially at low temperatures (optimum close to $17^{\circ} \mathrm{C}$ ), and mycelial growth along with orange spore masses develop on the crown and stem (15). The host range of the pathogen under natural conditions includes only cucumber,

Corresponding author: Demetrios J. Vakalounakis E-mail: vakalounakis@imbb.forth.gr

Present address G. C. Pavlou: National Agricultural Research Foundation (N.AG.RE.F.), Olive and Horticultural Crops Institute, Lakonikis 85, 24100 Kalamata, Greece.

Accepted for publication 27 November 2001.

Publication no. D-2002-0212-04R

๑) 2002 The American Phytopathological Society but under artificial inoculation conditions it extends to melon (C. melo L.) and gourd (Luffa aegyptiaca Mill.) (15). No race structure of the pathogen has been identified $(15,16)$.

The strategy for controlling root and stem rot of cucumber in Greece requires fumigation of soil with methyl bromide and disinfection of internal space of greenhouses with a formaldehyde solution. However, methyl bromide is expected to be banned from use in Greece by 1 January 2005. Therefore, alternative measures for disease management are urgently required. Cucurbits grafted onto various rootstocks to combat soilborne diseases, mainly caused by $F$. oxysporum, are common in various regions of the Mediterranean Basin, Far East, and other European countries $(3,4)$. In Greece, grafting is highly popular for watermelon and melon, especially in southern areas, where early cropping under low tunnels is practiced (13). However, grafting cucumbers onto resistant rootstocks is only currently employed in a low percentage (approximately 5\%) of greenhouse crops in Greece, perhaps due mainly to the current availability and high efficiency of methyl bromide and the high labor cost for grafting. In this study, several cucurbits were evaluated under growth chamber and greenhouse conditions as potential sources of rootstock for grafting commercial cucumber hybrids to protect against root and stem rot development.

\section{MATERIALS AND METHODS}

Evaluation of cucurbits for resistance to root and stem rot under growth chamber and greenhouse conditions. Nine potential rootstocks belonging to the family Cucurbitaceae (Table 1) were evaluated for resistance to root and stem rot in growth chamber and greenhouse experiments, conducted in organic substrate and soil, respectively, artificially inoculated with $F$. oxysporum f. sp. radiciscucumerinum. Seeds were sown in seedling trays filled with the organic substrate Belplanto (Klasmann-Deilmann GmbH, Geeste, Germany). In the growth chamber experiment, young plants at the three- to four-true-leaf stage were removed from the organic substrate, their roots were washed with tap water, and then plants were transplanted into sterilized organic substrate Belplanto in plastic pots (15 cm diameter). One hour before planting, the substrate was artificially inoculated with a spore suspension of one of three single-spore isolates 4C, 7A, or 68A of $F$. oxysporum f. sp. radicis-cucumerinum, which had been adjusted to $10^{6}$ spores per $\mathrm{ml}(1$ part inoculum/10 parts substrate, vol/vol). Plants were kept in growth chambers for 50 days at $21^{\circ} \mathrm{C}$ with a 12 -h photoperiod under mixed fluorescent and incandescent lamps, using a completely randomized design with 10 replicate plants per cucurbit species. The photosynthetic photon flux density (PPFD) at the plant canopy was approximately $150 \mu \mathrm{mol} \cdot \mathrm{s}^{-1} \cdot \mathrm{m}^{-2}$. Young cucumber plants of the susceptible cv. Brunex $F_{1}$ treated similarly and transplanted into organic substrate inoculated with the pathogen served as a control. Plants were watered daily, and no fertilizers were applied. The experiment was conducted twice.

The greenhouse experiment was carried out during the 1993-94 crop season in a nonheated greenhouse with temperatures fluctuating between 8 and $25^{\circ} \mathrm{C}$ at the N.AG.RE.F.-Plant Protection Institute of Heraklio, Crete. Within the greenhouse, plants were grown "in ground." Soil type was loam with $\mathrm{pH} 7.5$, total calcium carbonate $45 \%$, and electrical conductivity of $2 \mathrm{mS} / \mathrm{cm}$. Soil in the experimental plots was fumigated 1 month before planting with methyl bromide at a rate of $80 \mathrm{~g} / \mathrm{m}^{2}$. 
Ten days after fumigation, soil was artificially inoculated with the single-spore isolate $4 \mathrm{C}$ of $F$. oxysporum f. sp. radiciscucumerinum by spraying the soil surface with a spore suspension at a rate of $7 \times 10^{5}$ spores per $\mathrm{m}^{2}$. Soil was then irrigated and mixed 5 days later with a milling machine. Young plants of nine potential cucurbit rootstocks (Table 1), along with cucumber plants of the susceptible cv. Brunex $F_{1}$, which served as a control, were planted in two rows in each experimental plot $(4 \times 2$ m) on 15 September 1993 using a randomized complete block design with four replicates of 10 plants of each cucurbit. Plants were grown according to local horticultural practices. Final observations of disease incidence were made on 20 February 1994. All plants in both growth chamber and greenhouse experiments were classified either as resistant when they were healthy (no disease symptoms) or susceptible when they were dead or almost dead.

Evaluation of rootstocks for grafting cucumbers. Our objective was to investigate the compatibility (expressed as cucumber plant growth and fruit yield) between the commercial cucumber $\mathrm{cv}$. Brunex $F_{1}$, used as a scion, and various Cucurbita spp. previously found to be resistant to $F$. oxysporum f. sp. radiciscucumerinum, which were used as rootstocks. Two greenhouse experiments were carried out during the 1994-95 and 199596 crop seasons at the N.AG.RE.F.Agricultural Research Station of Ierapetra, Crete. Soil type was sandy loam with $\mathrm{pH}$ 7.6, total calcium carbonate $35 \%$, and electrical conductivity of $2 \mathrm{mS} / \mathrm{cm}$. Soil in the experimental plots was fumigated with methyl bromide and then artificially inoculated with $F$. oxysporum f. sp. radiciscucumerinum, as previously described. During the 1994-95 crop season, the rootstock/scion combinations A27/Brunex $F_{1}$, Cucurbita Ficifolia/Brunex $\mathrm{F}_{1}$, Patron $\mathrm{F}_{1} /$ Brunex $\mathrm{F}_{1}$, Peto $42.91 \mathrm{~F}_{1} /$ Brunex $\mathrm{F}_{1}$, TS-1358 $\quad F_{1} /$ Brunex $\quad F_{1}$, and TZ-148 $F_{1} /$ Brunex $F_{1}$ were evaluated. The graft combinations of Peto $42.91 \mathrm{~F}_{1} /$ Brunex $\mathrm{F}_{1}$,
TS-1358 $\quad \mathrm{F}_{1} /$ Brunex $\quad \mathrm{F}_{1}$, and TZ-148 $F_{1} /$ Brunex $F_{1}$, which exhibited the best plant growth, were further evaluated during the 1995-96 crop season.

In both greenhouse experiments, seeds of the cucumber cv. Brunex $F_{1}$ (scion) and the various Cucurbita spp. rootstocks were sown in seedling trays filled with the organic substrate Belplanto and kept in a nonheated greenhouse. Plants were grafted at the two-leaf stage using the tongue approach grafting (4). Scion and rootstock were held with a grafting clip (Sakata Seed Corporation, Yokohama, Japan). Grafted plants were kept in a small greenhouse under semicontrolled environmental conditions (relative humidity fluctuating between 70 and $90 \%$, and temperature fluctuating between 15 and $30^{\circ} \mathrm{C}$ ) until transplanting. The hypocotyls of the scion and the rootstock were cut below and above the graft union, respectively, 10 days after grafting. Ten days later, grafted plants were transplanted to a nonheated plastic house in two rows in each experimental plot $(1.3 \times 18 \mathrm{~m})$. Intra-row spacing was $50 \mathrm{~cm}$ and rows were $70 \mathrm{~cm}$ apart. There were four replicates of eight grafted plants per each treatment (rootstock), and the experiments utilized a randomized complete block design. Plots treated similarly, but sprayed with tap water instead of a spore suspension of the pathogen, served as a noninoculated control. Plants in all treatments were fertilized in a similar fashion and grown according to local horticultural practices.

During both greenhouse experiments, data on plant growth (height and number of leaves per plant) and commercial fruit yield were obtained, and the number of cucumber plants with symptoms of the root and stem rot disease was recorded. Plant height was measured along the plant stem from the soil line up to the growing tip and leaf number from the soil line up to a maximum of $1.80 \mathrm{~m}$ from the crown of the plant. No leaves from the lateral shoots were measured. Infection of cucumber plants was verified by isolating the patho- gen on Komada's medium and identifying it using the vegetative compatibility grouping method. Cucumber plants were classified as healthy when symptoms of disease were absent and the pathogen was not isolated or infected when disease symptoms were present and the pathogen was isolated from infected tissues. Disease incidence was estimated as the percentage of infected cucumber plants. Infection of rootstocks was checked by examining their roots and hypocotyl for any rot or discoloration of the vascular system and for possible isolation of the pathogen from non-discolored vessels, as described above.

In the first experiment (1994-95 crop season), seeds of scion (cucumber), rootstocks (Cucurbita spp.), and nongrafted (self-rooted) cucumber (control) were sown on 8 September, 10 September, and 15 September 1994, respectively. Plants were transplanted to the experimental plots on 10 October 1994. Final observations were taken on 31 March 1995. In the second experiment (1995-96 crop season), seeds of scion (cucumber), rootstocks $(\mathrm{Cu}$ curbita spp.), and nongrafted (self-rooted) cucumber (control) were sown on 23 September, 25 September, and 1 October 1995, respectively. Plants were transplanted to the experimental plots on 30 October 1995. Final observations were taken on 30 May 1996.

Statistical analysis. Analysis of variance was used to evaluate differences in disease incidence, plant height, number of leaves per plant, and fruit yield of cucumber under the various grafting conditions. Disease incidence data were arcsinetransformed before analysis. Treatments were thereafter compared by Fisher's least significant difference test $(P=0.05)$.

\section{RESULTS}

Evaluation of cucurbits for resistance to root and stem rot under growth chamber and greenhouse conditions. In both growth chamber and greenhouse experiments, all commercial cucurbits tested, which belonged to either the botanical

Table 1. Evaluation of various cucurbits as potential rootstocks with resistance to three isolates of Fusarium oxysporum f. sp. radicis-cucumerinum in growth chamber and greenhouse experiments carried out during the 1993-94 crop season at the N.AG.RE.F.-Plant Protection Institute of Heraklio, Crete

\begin{tabular}{|c|c|c|c|c|c|c|}
\hline \multirow[b]{3}{*}{ Commercial name } & \multirow[b]{3}{*}{ Species } & \multirow[b]{3}{*}{ Seed production company } & \multicolumn{4}{|c|}{ Disease reaction $^{y}$} \\
\hline & & & \multicolumn{3}{|c|}{ Growth chamber experiments } & \multirow{2}{*}{$\begin{array}{l}\text { Greenhouse } \\
\text { experiment }\end{array}$} \\
\hline & & & $4 \mathrm{C}$ & 7A & 68A & \\
\hline A27 & Cucurbita ficifolia & Hybrids Hellas, Greece & $\mathrm{R}$ & $\mathrm{R}$ & $\mathrm{R}$ & $\mathrm{R}$ \\
\hline Cucurbita Ficifolia & Cucurbita ficifolia & Enza Zaden, The Netherlands & $\mathrm{R}$ & $\mathrm{R}$ & $\mathrm{R}$ & $\mathrm{R}$ \\
\hline Kirameki $\mathrm{F}_{1}$ & Cucurbita moschata & Takii Seed, Japan & $\mathrm{R}$ & $\mathrm{R}$ & $\mathrm{R}$ & $\mathrm{R}$ \\
\hline Patron $\mathrm{F}_{1}$ & Cucurbita moschata & Takii Seed, Japan & $\mathrm{R}$ & $\mathrm{R}$ & $\mathrm{R}$ & $\mathrm{R}$ \\
\hline Brava $\mathrm{F}_{1}$ & Cucurbita maxima $\times C$. moschata & Petoseed, U.S.A. & $\mathrm{R}$ & $\mathrm{R}$ & $\mathrm{R}$ & $\mathrm{R}$ \\
\hline Peto $42.91 \mathrm{~F}_{1}$ & Cucurbita maxima $\times$ C. moschata & Petoseed, U.S.A. & $\mathrm{R}$ & $\mathrm{R}$ & $\mathrm{R}$ & $\mathrm{R}$ \\
\hline Tetsukabuto $\mathrm{F}_{1}$ & Cucurbita maxima $\times C$. moschata & Takii Seed, Japan & $\mathrm{R}$ & $\mathrm{R}$ & $\mathrm{R}$ & $\mathrm{R}$ \\
\hline TS-1358 $\mathrm{F}_{1}$ & Cucurbita maxima $\times$ C. moschata & Hybrids Hellas, Greece & $\mathrm{R}$ & $\mathrm{R}$ & $\mathrm{R}$ & $\mathrm{R}$ \\
\hline $\mathrm{TZ}-148 \mathrm{~F}_{1}$ & Cucurbita maxima $\times$ C. moschata & Tezier, France & $\mathrm{R}$ & $\mathrm{R}$ & $\mathrm{R}$ & $\mathrm{R}$ \\
\hline Brunex $\mathrm{F}_{1}$ (control) & Cucumis sativus & Hybrids Hellas, Greece & $\mathrm{S}$ & $\mathrm{S}$ & $\mathrm{S}$ & $\mathrm{S}$ \\
\hline
\end{tabular}

${ }^{y} \mathrm{R}=$ resistant reaction, healthy plants; $\mathrm{S}=$ susceptible reaction, plants dead or almost dead. The growth chamber experiment was conducted twice with 10 replicate plants per cucurbit species. In the greenhouse experiment, there were four replicates of 10 plants of each cucurbit.

${ }^{\mathrm{z}}$ Soil was artificially inoculated with the single-spore isolate $4 \mathrm{C}$ of Fusarium oxysporum $\mathrm{f}$. sp. radicis-cucumerinum. 
species $C$. ficifolia and C. moschata or the interspecific hybrid $C$. maxima $\times C$. moschata, were found to be resistant (no disease symptoms) to all three isolates of $F$. oxysporum f. sp. radicis-cucumerinum (Table 1). In contrast, cucumber cv. Brunex $F_{1}$ (control) was found to be susceptible; all plants were almost dead or dead (Table 1).

Evaluation of rootstocks used for grafting cucumbers. In the first experiment (1994-95 crop season), height and number of leaves of cucumber plants cv. Brunex $F_{1}$ grafted onto the rootstocks Peto $42.91 \mathrm{~F}_{1}$, TS-1358 $\mathrm{F}_{1}$, and TZ-148 $\mathrm{F}_{1}$ were greater than those of cucumber plants $\mathrm{cv}$. Brunex $F_{1}$ grafted onto the rootstocks A27, Cucurbita Ficifolia, and Patron $F_{1}$, as well as of the nongrafted (self-rooted) plants cv. Brunex $\mathrm{F}_{1}$ (control) (Table 2). Total fruit yield of cucumber plants cv. Brunex $F_{1}$ grafted onto all rootstocks tested was greater than that of the nongrafted (selfrooted) plants cv. Brunex $\mathrm{F}_{1}$ (control) (Table 2). In the second experiment (1995-96 crop season), no differences were observed in the height, number of leaves, and fruit yield among cucumber plants cv. Brunex $\mathrm{F}_{1}$ grafted onto the rootstocks Peto 42.91 $F_{1}$, TS-1358 $F_{1}$, and TZ-148 $F_{1}$, but they were greater than those of nongrafted (selfrooted) cucumbers (Table 2). These differences were much greater in the $F$. $o x$ - ysporum f. $\quad \mathrm{sp}$. radicis-cucumerinuminoculated soil than in the uninoculated soil (Table 2).

In both greenhouse experiments, none of the rootstocks were infected by $F$. oxysporum f. sp. radicis-cucumerinum. However, during the midseason, a low percentage (up to a maximum of 12 and $8 \%$ in the first and second crop seasons, respectively) of cucumber scions grafted onto all rootstocks tested showed disease symptoms. This infection was probably due to contact of the cucumbers with contaminated soil; the resulting inoculation could then have been spread to the grafting union area by air or splash of water dropping from the plastic greenhouse cover. In addition, a very low percentage (up to a maximum of 13 and $8 \%$ in the first and second crop seasons, respectively) of cucumber plants were infected by $F$. oxysporum f. sp. radicis-cucumerinum. Infection could have occurred through the formation of adventitious roots developing at the graft union, which reached the contaminated soil. The total percentages of diseased cucumber plants grafted on each rootstock are shown in Table 3.

\section{DISCUSSION}

The most popular rootstock species used worldwide for grafting cucumbers are $C$. ficifolia Bouche, C. moschata (Duchesne) Duchesne ex Poir., Sicyos angulatus L., and the interspecific hybrid $C$. maxima Duchesne $\times C$. moschata, which protect the cucumbers against the soilborne pathogens Fusarium oxysporum f. sp. cucumerinum and Phytophthora parasitica $(4,14 ; \mathrm{T}$.

Table 3. Disease incidence (\%) from Fusarium oxysporum f. sp. radicis-cucumerinum of cucumber plants cv. Brunex $F_{1}$ grafted onto various rootstocks in two greenhouse experiments carried out during the 1994-95 and 1995-96 crop seasons at the N.AG.RE.F.-Agricultural Research Station of Ierapetra, Crete ${ }^{\mathrm{y}}$

\begin{tabular}{lcc}
\hline & \multicolumn{2}{c}{ Disease incidence (\%) } \\
\cline { 2 - 3 } Rootstock & $\mathbf{1 9 9 4 - 9 5}$ & $\mathbf{1 9 9 5 - 9 6}$ \\
\hline A27 & $25.0 \mathrm{~b}^{\mathrm{z}}$ & $\mathrm{nt}$ \\
Cucurbita Ficifolia & $25.0 \mathrm{~b}$ & $\mathrm{nt}$ \\
Patron $\mathrm{F}_{1}$ & $21.5 \mathrm{c}$ & $\mathrm{nt}$ \\
Peto $42.91 \mathrm{~F}_{1}$ & $12.5 \mathrm{~d}$ & $9.4 \mathrm{c}$ \\
TS-1358 $\mathrm{F}_{1}$ & $12.5 \mathrm{~d}$ & $0.0 \mathrm{~d}$ \\
TZ-148 $\mathrm{F}_{1}$ & $21.5 \mathrm{c}$ & $15.6 \mathrm{~b}$ \\
Brunex $\mathrm{F}_{1}$ & $96.9 \mathrm{a}$ & $100 \mathrm{a}$ \\
(nongrafted, control) & & \\
\hline
\end{tabular}

${ }^{y}$ In the experiments of both crop seasons there were four replicates of eight grafted plants per each treatment.

${ }^{\mathrm{z}}$ Within columns, means followed by the same letters are not significantly different $(P=$ 0.05 ) according to Fisher's least significant difference test; $\mathrm{nt}=$ not tested.

Table 2. Height, number of leaves, and total yield of cucumber plants of the cv. Brunex $F_{1}$ grafted onto various rootstocks in two greenhouse experiments carried out during the 1994-95 and 1995-96 crop seasons at the N.AG.RE.F.-Agricultural Research Station of Ierapetra, Crete ${ }^{\mathrm{y}}$

\begin{tabular}{|c|c|c|c|c|c|c|c|c|}
\hline \multirow[b]{3}{*}{ Rootstocks } & \multicolumn{5}{|c|}{ Artificially inoculated soil } & \multirow{2}{*}{\multicolumn{3}{|c|}{$\begin{array}{c}\text { Uninoculated soil } \\
1995-96 \text { crop season }\end{array}$}} \\
\hline & \multicolumn{2}{|c|}{ 1994-95 crop season } & \multicolumn{3}{|c|}{ 1995-96 crop season } & & & \\
\hline & 27 Oct. 94 & 4 Nov. 94 & 21 Dec. 95 & 10 Jan. 96 & 21 Feb. 96 & 21 Dec. 95 & 10 Jan. 96 & 21 Feb. 96 \\
\hline \multicolumn{9}{|l|}{ A27 } \\
\hline Plant height $(\mathrm{cm})$ & $104.7 \mathrm{~B}^{\mathrm{z}}$ & $163.1 \mathrm{~B}$ & $\mathrm{nt}$ & $\mathrm{nt}$ & $\mathrm{nt}$ & $\mathrm{nt}$ & $\mathrm{nt}$ & $\mathrm{nt}$ \\
\hline No. leaves/plant & $17.8 \mathrm{~b}$ & $24.8 \mathrm{~b}$ & $\mathrm{nt}$ & $\mathrm{nt}$ & $\mathrm{nt}$ & $\mathrm{nt}$ & $\mathrm{nt}$ & $\mathrm{nt}$ \\
\hline Total yield $(\mathrm{kg}) /$ plant & \multicolumn{2}{|c|}{$5.3 \mathrm{c}$} & & nt & & & nt & \\
\hline \multicolumn{9}{|l|}{ Cucurbita Ficifolia } \\
\hline Plant height $(\mathrm{cm})$ & $113.5 \mathrm{~B}$ & $173.6 \mathrm{~B}$ & $\mathrm{nt}$ & $\mathrm{nt}$ & $\mathrm{nt}$ & $\mathrm{nt}$ & $\mathrm{nt}$ & $\mathrm{nt}$ \\
\hline No. leaves/plant & $18.2 \mathrm{~b}$ & $25.5 \mathrm{~b}$ & nt & nt & nt & $\mathrm{nt}$ & $\mathrm{nt}$ & nt \\
\hline Total yield $(\mathrm{kg}) /$ plant & \multicolumn{2}{|c|}{$5.6 \mathrm{bc}$} & & $\mathrm{nt}$ & & & nt & \\
\hline \multicolumn{9}{|l|}{ Patron } \\
\hline Plant height $(\mathrm{cm})$ & $112.6 \mathrm{~B}$ & $175.2 \mathrm{~B}$ & nt & nt & nt & nt & $\mathrm{nt}$ & nt \\
\hline No. leaves/plant & $18.3 \mathrm{~b}$ & $25.5 \mathrm{~b}$ & $\mathrm{nt}$ & $\mathrm{nt}$ & $\mathrm{nt}$ & $\mathrm{nt}$ & $\mathrm{nt}$ & $\mathrm{nt}$ \\
\hline Total yield $(\mathrm{kg}) /$ plant & \multicolumn{2}{|c|}{$6.2 \mathrm{abc}$} & & $\mathrm{nt}$ & & & nt & \\
\hline \multicolumn{9}{|l|}{ Peto 42.91} \\
\hline Plant height $(\mathrm{cm})$ & $142.9 \mathrm{~A}$ & $210.6 \mathrm{~A}$ & $125.3 \mathrm{~A}$ & $168.1 \mathrm{~A}$ & $220.0 \mathrm{~A}$ & $125.9 \mathrm{~A}$ & $175.8 \mathrm{~A}$ & $229.3 \mathrm{~A}$ \\
\hline No. leaves/plant & $20.7 \mathrm{a}$ & $28.0 \mathrm{a}$ & $24.5 \mathrm{a}$ & $32.4 \mathrm{a}$ & $41.8 \mathrm{a}$ & $25.1 \mathrm{a}$ & $32.9 \mathrm{a}$ & $42.5 \mathrm{a}$ \\
\hline Total yield $(\mathrm{kg}) /$ plant & \multicolumn{2}{|c|}{$7.4 \mathrm{a}$} & & $7.6 \mathrm{a}$ & & & $8.2 \mathrm{a}$ & \\
\hline \multicolumn{9}{|l|}{ TS-1358 } \\
\hline Plant height $(\mathrm{cm})$ & $133.7 \mathrm{~A}$ & $203.1 \mathrm{~A}$ & $126.1 \mathrm{~A}$ & $170.9 \mathrm{~A}$ & $225.3 \mathrm{~A}$ & $128.0 \mathrm{~A}$ & $175.8 \mathrm{~A}$ & $225.8 \mathrm{~A}$ \\
\hline No. leaves/plant & $19.5 \mathrm{a}$ & $27.2 \mathrm{a}$ & $24.3 \mathrm{a}$ & $32.4 \mathrm{a}$ & $42.2 \mathrm{a}$ & $25.4 \mathrm{a}$ & $32.9 \mathrm{a}$ & $42.3 \mathrm{a}$ \\
\hline Total yield $(\mathrm{kg}) /$ plant & \multicolumn{2}{|c|}{$6.7 \mathrm{ab}$} & & $7.5 \mathrm{a}$ & & & $7.9 \mathrm{a}$ & \\
\hline \multicolumn{9}{|l|}{ TZ-148 } \\
\hline Plant height $(\mathrm{cm})$ & $132.3 \mathrm{~A}$ & 202.4 A & $126.3 \mathrm{~A}$ & $171.2 \mathrm{~A}$ & $226.0 \mathrm{~A}$ & $123.5 \mathrm{~A}$ & $174.2 \mathrm{~A}$ & $228.5 \mathrm{~A}$ \\
\hline No. leaves/plant & $19.6 \mathrm{a}$ & $27.3 \mathrm{a}$ & $24.9 \mathrm{a}$ & $32.7 \mathrm{a}$ & $42.8 \mathrm{a}$ & $25.2 \mathrm{a}$ & $33.0 \mathrm{a}$ & $43.2 \mathrm{a}$ \\
\hline Total yield $(\mathrm{kg}) /$ plant & \multicolumn{2}{|c|}{$6.8 \mathrm{ab}$} & & $8.3 \mathrm{a}$ & & & $8.4 \mathrm{a}$ & \\
\hline \multicolumn{9}{|l|}{$\begin{array}{l}\text { Nongrafted cucumbers } \\
\text { (control) }\end{array}$} \\
\hline Plant height $(\mathrm{cm})$ & $105.2 \mathrm{~B}$ & $162.9 \mathrm{~B}$ & $64.7 \mathrm{~B}$ & $106.5 \mathrm{~B}$ & $132.5 \mathrm{~B}$ & $95.2 \mathrm{~B}$ & $146.6 \mathrm{~B}$ & $202.8 \mathrm{~b}$ \\
\hline No. leaves/plant & $18.2 \mathrm{~b}$ & $25.3 \mathrm{~b}$ & $14.3 \mathrm{~b}$ & $22.0 \mathrm{~b}$ & $22.8 \mathrm{~b}$ & $21.2 \mathrm{~b}$ & $29.9 \mathrm{~b}$ & $39.3 \mathrm{~b}$ \\
\hline Total yield $(\mathrm{kg}) /$ plant & \multicolumn{2}{|c|}{$2.8 \mathrm{~d}$} & & $0.0 \mathrm{~b}$ & & & $6.6 \mathrm{~b}$ & \\
\hline
\end{tabular}

${ }^{y}$ In the experiments of both crop seasons there were four replicates of eight grafted plants per each treatment.

${ }^{\mathrm{z}}$ Within columns, means followed by the same letters are not significantly different $(P=0.05)$ according to Fisher's least significant difference test; nt $=$ not tested. 
Kanno, personal communication). Since root and stem rot $(F$. oxysporum f. sp. radicis-cucumerinum) is a new disease of cucumber $(15,16)$, the possible use of grafting cucumbers onto resistant rootstocks to protect against this disease has not yet been examined. In our growth chamber and greenhouse experiments, it was found that $C$. ficifolia, C. moschata, and $C$. maxima $\times C$. moschata are resistant to $F$. oxysporum f. $\mathrm{sp}$. radiciscucumerinum; therefore, they could be used as rootstocks for grafting cucumbers to protect against root and stem rot.

Data obtained in this study suggest that grafting the susceptible cucumber cv. Brunex $F_{1}$, and possibly other Dutch type cucumber hybrids, onto $C$. ficifolia, $C$. moschata, and C. maxima $\times C$. moschata is an effective control measure against root and stem rot. When cv. Brunex $F_{1}$ scions were grafted onto the above rootstocks, root and stem rot was significantly reduced (by 75 to $100 \%$ ). The low incidence of diseased plants (maximum 25\%), observed in cucumber at the end of the crop season, without preceding infection of the Cucurbita rootstocks, was probably due either to contact of the cucumber stem base at the grafting union area with contaminated soil transferred by air or water splash, or to a cucumber root that developed at the grafting area reaching the contaminated soil. However, this low percentage of diseased cucumber plants could be minimized by improving the grafting technique (e.g., using seedlings at early stages where the pith of the rootstock hypocotyl is compact and therefore does not favor the development and movement of roots through it, and performing the grafting on the rootstock hypocotyl as high as possible) or by preventing the transfer of contaminated soil dust to the scion by air (e.g., covering the soil with a plastic film) or water splash (e.g., using an antifogging plastic cover to prevent dripping of condensed vapor of water).

Our results have shown that the increase in cucumber yield through the use of grafted plants can be attributed mainly to disease control and secondly to better plant growth. Increased plant growth responses, not related to the control of a major pathogen, are a well-known phenomenon in grafted plants (4). The rootstock's vigorous root system is often capable of absorbing water and nutrients more efficiently than scion roots, and may serve as a supplier of additional endogenous plant hormones $(4,10)$. Cucurbits usually show a significant amount of xylem sap after vine cut, greatly influenced by the rootstock and containing high concentrations of minerals, organic substances, and plant hormones (cytokinins and gibberellins) (1,2,6-8). This may explain the increased plant growth and yield of cucumbers observed in our experiments when Cucurbita rootstocks were used.

Grafted Dutch type cucumber plants on C. maxima $\times$ C. moschata rootstocks are more expensive, since both scions and rootstocks are expensive hybrids. In addition, the development of grafted plants requires more time, materials, space, a high level of expertise, improved cultivation methods, and expensive postgraft handling. Also, growers must graft numerous seedlings within a limited period. However, the development of grafted cucumbers in Greece after 1 January 2005 , when the use of methyl bromide will be phased out, is expected to increase significantly despite the high cost of labor and supplies, since grafting is the unique alternative effective control method found up to now for root and stem rot. Extensive efforts to overcome the labor problem are being made in Japan $(3,5)$, where private companies, research institutions, and universities are attempting to develop feasible grafting robots. In the future, it may be common practice for growers to use grafted plants produced by robots $(3,5)$.

\section{ACKNOWLEDGMENTS}

We thank Matthew Dickinson (University of Nottingham, Plant Science Division, School of Biosciences, England) for helpful comments on the manuscript.

\section{LITERATURE CITED}

1. Biles, C. L., Martyn, R. D., and Wilson, H. D. 1989. Isozymes and general proteins from various watermelon cultivars and tissue types. HortScience 24:810-812.

2. Kato, T., and Lou, H. 1989. Effect of rootstock on the yield, mineral nutrition and hormone level in xylem sap in eggplant. J. Jpn. Soc. Hortic. Sci. 58:345-352.

3. Kurata, K. 1994. Cultivation of grafted vege- tables. II. Developing of grafting robots in Japan. HortScience 29:240-244.

4. Lee, J.-M. 1994. Cultivation of grafted vegetables. I. Current status, grafting methods, and benefits. HortScience 29:235-239

5. Lee, J.-M., Bang, H.-J., and Ham, H.-S. 1998 Grafting of vegetables. J. Jpn. Soc. Hortic. Sci. 67:1098-1104.

6. Masuda, M. and Gomi, K. 1982. Diurnal changes of the exudation rate and the mineral concentration in xylem sap after decapitation of grafted and non-grafted cucumber. J. Jpn. Soc. Hortic. Sci. 51:293-298.

7. Masuda, M., and Gomi, K. 1984. Mineral absorption and oxygen consumption in grafted and nongrafted cucumber. J. Jpn. Soc. Hortic. Sci. 52:414-419.

8. Masuda, M., Nakamura, T., and Gomi, K. 1981. Studies on the characteristics of nutrient absorption of rootstocks in grafting of fruit vegetables. II. Effect of rootstock, $\mathrm{Cu}$ curbita ficifolia on the growth and mineral composition of xylem sap in cucumber in relation to potassium concentration in culture system. Bull. Fac. Agric., Miyazaki University, Miyazaki, Japan 27:187-194.

9. Moreno, A., Alferez, A., Aviles, M., Dianez, F., Blanco, R., Santos, M., and Tello, J. C. 2001. First report of Fusarium oxysporum $\mathrm{f}$. sp. radicis-cucumerinum on cucumber in Spain. Plant Dis. 85:1206.

10. Pulgar, G., Villora, D. A., Moreno, D. A., and Romero, L. 2000. Improving the mineral nutrition in grafted watermelon plants: nitrogen metabolism. Biol. Plant. 43:607-609.

11. Punja, Z. K., and Parker, M. 2000. Development of Fusarium root and stem rot, a new disease on greenhouse cucumber in British Columbia, caused by Fusarium oxysporum $\mathrm{f}$. sp. radicis-cucumerinum. Can. J. Plant Pathol. 22:349-363.

12. Reverchon, S., Monnet, Y., Beliard, E., and Alabouvette, C. 2000. Du nouveau sur les fusarioses du concombre. Fusarium oxysporum f. sp. radicis-cucumerinum (FORC) isolé pour la première fois en France. Phytoma 530:36-38.

13. Traka-Mavrona, E., Koutsika-Sotiriou, M., and Pritsa, T. 2000. Response of squash $(\mathrm{Cu}$ curbita spp.) as rootstock for melon (Cucumis melo L.) Sci. Hortic. 83:353-362.

14. Vakalounakis, D. J. 1988. Diseases and pests of vegetable crops and their control. Technological Education Institute, Heraklio, Greece.

15. Vakalounakis, D. J. 1996. Root and stem rot of cucumber caused by Fusarium oxysporum f. sp. radicis-cucumerinum f. sp. nov. Plant Dis. 80:313-316.

16. Vakalounakis, D. J., and Fragkiadakis, G. A. 1999. Genetic diversity of Fusarium oxysporum isolates from cucumber: Differentiation by pathogenicity, vegetative compatibility, and RAPD fingerprinting. Phytopathology 89:161-168. 